\title{
Exploring Service Quality Dimensions of IT Shared Services in the Malaysian Public Sector
}

\author{
Siti Mariam Shahar ${ }^{1}$, Nurhizam Safie Mohd Satar ${ }^{2}$, Khairul Azmi Abu Bakar ${ }^{3}$ \\ Universiti Kebangsaan Malaysia (UKM), Research Center for Software Technology and Management \\ (SOFTAM), Faculty of Information Science and Technology, 43600 Bangi, Malaysia \\ ${ }^{1}$ P89063@ siswa.ukm.edu.my \\ 2nurhizam@ukm.edu.my \\ ${ }^{3}$ khairul.azmi@ukm.edu.my
}

\begin{abstract}
Sharing services is an increasingly viable business strategy involving the consolidation of support functions managed by one agency or known as a shared service organization or shared service center. The intention is to provide a more effective and efficient service to the organization. In order to ensure that the service quality of the shared services is consistently excellent, customer satisfaction is one of the best tools to measure the performance level of the services provided. There have been few studies on shared services relating to the Information Systems domain. Thus, there are many research opportunities, especially for the outcome and evaluation phases. For this research, we need to know the relevant quality dimension for shared services. This paper explores the dimensions and factors of service quality for IT Shared Services. It then develops the service quality model for measuring IT shared services customer satisfaction based on past studies and interviews with shared services IT managers in MAMPU. Three case studies on IT infrastructure shared services in the public sector of Malaysia are used. This article recommends nine (9) dimensions, namely tangibles, reliability, responsiveness, assurance, empathy, continuous service improvement, change management, technology availability and security. The dimensions identified will assist the shared service organization in giving priority attention to improving service quality delivery.
\end{abstract}

Key words: IT Shared Services; Shared Services; Service Quality; Customer Satisfaction.

\section{INTRODUCTION}

The existence of IT infrastructure shared services; IT data center, IT network and IT communications are the backbone to the overall digital initiatives in doing businesses such as online applications, social media and big data projects. IT Infrastructure Shared Services (ITISS) initiative simplifies the integration of IT operations which cover the Wide Area Network (WAN), data center, and common application operations at one central agency called the Shared Service
Organization (SSO) or Shared Service Centre (SSC). The initiative has strengthened the IT model, simplified the system, avoided overlapping and fully utilized the technology to increase the government service delivery. IT infrastructure is an important element in the successful implementation and service delivery of any IS application. Evaluating ITISS service quality can be achieved through measuring customer or ITISS team satisfaction and performance.

The measurement of its customer satisfaction level is essential to ensure benefits are gained. Among the important drivers to adopt shared services in the public sector are to achieve a more efficient service delivery, improve the service performance level and boost service [1], [2], to achieve more efficient daily operations and save cost [3], [4]. However, there is limited data on service quality for ITISS [5]-[7]. Only a few previous studies on evaluation shared services related to human resource have been done and they show negative effects, in that implementing shared services reduces customer satisfaction [5], [8]. Past studies have acknowledged the limitation of shared services in an Information Systems (IS) and broadening the scope of the study is recommended [6], [7]. To the best of our knowledge, there have been few studies on customer satisfaction with IT shared services [7]. Since MPS has used ITISS for more than 5 years, it is time to evaluate it. Our findings will contribute to the literature on the quality of shared service in the IS domain in the public sector. Hence, it is critical to have a quality model for customer satisfaction of ITISS development which is aligned with SSO and ITISS requirements.

The aim of this study is to explore the outline of ITISS implementation in Malaysia and identify the crucial dimensions of service quality that leads to ITISS customer satisfaction. The Service Quality Model (SERVQUAL) [9] and DeLone and McLean model [10] are used in this study in the determination of ITISS service quality dimensions. The early part of this study will describe the three types of ITISS at Malaysian Public Sector which selected as a case study to identify shared service quality dimension. Based on the literature review and case study from ITISS in Malaysia, the dimension of the initial service quality model for ITISS is proposed. 


\section{LITERATURE REVIEW}

This section is discussed on three (3) component as follows; Part A describes the Shared Services. Part B explains the service quality and customer satisfaction and Part C presents IT Infrastructure Shared Services in the Malaysian Public Sector as a case study.

\subsection{Shared Services}

In the public sector, the benefit of the shared services is reducing costs, improving access to innovation and allowing an increased focus on core operation [4]. [11] claims that the SSC is not business as usual and it differs from centralized models and outsourcing models. The outsourcing arrangement acknowledges the relationship between a single client and several external vendors. Meanwhile, the SSC arrangement acknowledges many clients and a single external vendor, giving provision for both as one and the same organization [1].

Indeed, there is a motivation in shared services implementation such as to improve service quality, service consistency, internal exchange capability, subject matter expert identification and external source accessibility [12]. For a decade, shared services has become the preferred and attractive choice for public and private sectors [13]-[15]. In general, shared services in finance or human resource domain has been implemented extensively and together with shared services for IS, which has grown rapidly [7], [16].

The shared services also have the potential to utilize IT related resources in the coordination and implementation process, become faster and more accurate and make a greater impact on organizations. The IT infrastructure shared services may need to be changed radically to suit the specific need of business units or customers. A current review of shared services stated that only $4 \%$ of research in shared services were done involving customers [7]. This is quite surprising because shared services is a customer-oriented concept and supposedly requires the understanding of customers' needs. Focusing on people, process and technology are necessary for evaluation of IT Shared services management [11]. Since ITISS in Malaysia Public Sector has been implemented for more than five years, it is an appropriate and crucial time for the needs to focus on the outcome-based perspective such as performance determination.

\subsection{Service quality and customer satisfaction}

\section{A. Service Quality}

Service quality can be discussed in a wide range of subjects from service quality related ideas to expected and perceived services. Reference [17] mentioned that if the services received are as per predicted, the service quality is adequate. However, if the service received surpass the prediction, the customer will be overwhelmed and will perceive the service quality as outstanding and vice versa.
There are various service quality model and relevant research available in various field are on-going. Reference [18] and [17] were constituted among the models for customer service satisfaction appraisal has widely been used in various fields. Whereas, DeLone and McLean [10] have identified a six-factor IS success model as taxonomy and a framework of investigation of the relevant dependent variables. Based on the review, it was discovered the similarity between all the model, particularly in the service quality dimension. Clearly, SERVQUAL dimensions have been used in DeLone and McLean's category for core component as; information of quality, system quality and service quality. Hence, four models have been selected as the main reference by the majority of a researcher in various domain and one new relevance model for IT services as stipulated in Table 1 below:

Table 1: Service Quality Dimensions

\begin{tabular}{|c|c|c|}
\hline References & Category & Dimensions \\
\hline [17] & Service Quality & $\begin{array}{l}\text { Tangibles, Assurance, } \\
\text { Reliability, } \\
\text { Responsiveness, } \\
\text { Empathy }\end{array}$ \\
\hline [18] & $\begin{array}{l}\text { Functional } \\
\text { Quality } \\
\text { Process Quality }\end{array}$ & $\begin{array}{l}\text { Management structures, } \\
\text { Administrative support, } \\
\text { Responsiveness, } \\
\text { Assurance, Continuous } \\
\text { Service Improvement, } \\
\text { Change Management }\end{array}$ \\
\hline \multirow[t]{3}{*}[10]{} & System quality & $\begin{array}{l}\text { Adaptability, } \\
\text { Availability, Reliability, } \\
\text { Response time, } \\
\text { Usability }\end{array}$ \\
\hline & $\begin{array}{l}\text { Information } \\
\text { quality }\end{array}$ & $\begin{array}{l}\text { Completeness, Ease of } \\
\text { understanding, } \\
\text { Personalization, } \\
\text { Relevance, Security, } \\
\text { Service }\end{array}$ \\
\hline & Service quality & $\begin{array}{l}\text { Assurance, Empathy, } \\
\text { Responsiveness }\end{array}$ \\
\hline [11] & $\begin{array}{l}\text { People, Process } \\
\text { and } \\
\text { Technology }\end{array}$ & $\begin{array}{l}\text { Honesty, Clarity, } \\
\text { Personalized Attention, } \\
\text { Cost, Quality, Touch } \\
\text { Point Continuity, } \\
\text { Transaction Memory }\end{array}$ \\
\hline [19] & $\begin{array}{l}\text { Service quality } \\
\text { for IT Services } \\
\text { offering }\end{array}$ & $\begin{array}{l}\text { Reliability, } \\
\text { Responsiveness, } \\
\text { Assurance, Empathy, } \\
\text { Tangibles, Competence, } \\
\text { Credibility, } \\
\text { Accessibility, } \\
\text { Communication, } \\
\text { Understanding, } \\
\text { Consulting Price, } \\
\text { Offering, Clout, } \\
\text { Geographics }\end{array}$ \\
\hline
\end{tabular}


The five dimensions for service quality introduced by [17] have been used widely in many domains such as transportation, tourism, education and health. It also adopted in the recent study related to IT Services [19]. In reference to DeLone and McLean Information System success model, it has been used widely and mainly focus on application for e-commerce and other systems application [10]. However, the dimension in the model such as system quality and data quality can be adapted to measure the IT infrastructure services. For instance, system quality can be adopted as infrastructure quality for ITISS. We adopt service quality dimensions from SERVQUAL as the main basis for ITISS quality.

In the context of ITISS, the customer satisfaction level takes into account the quality service aspect and the service delivery process managed by the SSO. The service delivery in ITISS involves SSO and service provider companies which are appointed to provide quality services to customers. Therefore, MAMPU as an SSO should be able to monitor and maintain customers at a satisfactory level. This study proposed to cover all the SERVQUAL dimensions and selected relevant dimensions from DeLone and McLean.

\section{B. Customer Satisfaction}

There are many models or instruments available to evaluate customer satisfaction which has been introduced previously by researchers in the marketing field. The definition of customer satisfaction somewhat varies and normally meant to measure one product or service available to meet organization expectation [17], [20], [21]. Reference [11] stated that internal and external customers are among the most important stakeholders in a shared business unit.

By recognizing the importance and criticality of ITISS in MPS, fulfilling customer satisfaction from different categories and needs is a very challenging task for MAMPU. The basic needs of all customers should be met over time and MAMPU must always be ready to offer new services when necessary or requested. ITISS is a long-term commitment whereas the services should fulfil the customer requirement. In the long run, the satisfaction should not measure only from the outcome or product, but the process involves should be included [21].

In the event that a customer is unsatisfied and refused to use ITISS, the implementation may fail. Previous studies have proved that the customer satisfaction level has reduced after implementing shared services [5], [8], [22]. We found that study related to customer services are continuously implemented in various domains. Recent research on customer satisfaction with Information Systems is related to IT applications such as e-commerce, online applications and software as a service (SaaS) [23]-[25]. Hence, the study related to ITISS towards customer satisfaction will help the management to keep enhancing the ITISS adequately and efficiently to all customers.

\subsection{IT Infrastructure Shared Services in Malaysian Public Sector}

In general, IT can be categorized into three perspectives which are applications, infrastructures and data/information. This is supported by [16] who explains that there are three (3) categories from a technology perspective for sharing services; (a) IT applications (shared application software and applications), (b) data or information (data or information that can be shared within the organization) and (c) IT infrastructure (hardware, storage and shareable networks). This study will focus on the three ITISS programs which are related to:

a) IT networking (MyGov*Net- provides a platform to access government electronic applications, agencies' internal applications and internet access);

b) IT data Centre (PDSA- provides physical \& virtual server hosting, data centre and disaster recovery centre (DRC), gateway viruswall, backup \& restore and support services); and

c) IT communications shared services (MyGovUC- service combines channels of communication via e-mail, video and audio conferencing, instant messaging, facsimile, short message system (SMS) and Identity Management System)

These three ITISS are key aspects of the Eleventh Malaysian Plan (2016-2020). The aim is to increase efficiency and reduce redundancy [26]. MAMPU as an SSO is responsible for providing those three main IT infrastructure shared services to the government agencies nationwide [26]. It is a long-term commitment where the agencies have to use the ITISS provided whether they like it or not. It is a challenge for MAMPU to ensure the service quality of ITISS is at par or above the previous service quality received by the customers. MAMPU needs to tackle and manage the ITISS by looking at all aspects of management to ensure the quality of services delivered to the customers.

\section{RESEARCH METHODOLOGY}

This is an exploratory study with the intention to identify the dimensions of service quality for ITISS. This method was chosen due to the limited study involving the customer in shared services research and the importance of service quality offered to the customers. This study dealt with an extensive and complex issue. Furthermore, it was noted that insufficient knowledge in this field. Hence, the study focuses on the context of the occurrence [27]. Two methods adopted are content analysis and experts' opinion. The dimensions of service quality related to the IT shared services are identified by conducting content analysis. Research databases subscribed by the university, open search, and reliable websites are used to obtain the relevant papers. The keywords used are "shared service", "IT/IT shared services" and "service quality" and only articles written in English are chosen in this study. Then, the SERVQUAL dimensions are designed as the main code to match with the study objective. This was followed by actual coding of the relevant text. Then an evaluation is made on the coded text whether there is a 
need to create a new code dimension. Finally, we analysed the coded text under each node and reporting the findings.

Furthermore, experts' opinion is also considered in this study. Based on experts' opinion, the proposed dimensions were derived in accordance with academic and practical viewpoints. In order to address the above-outlined objectives, reports were reviewed and a number of interviews were conducted. The interviews were commenced from September 2017 to May 2018, whereas nine (9) interviews were conducted by researchers for three ITISS cases. The interviews are recorded and transcribes. Then, the first author emails the transcribe to the interviewees for confirmation or any additional information. This will ensure the reliability of data interviews. The experts' characteristics are as shown in Table 2.

Table 2: Experts for Case Study

\begin{tabular}{|c|c|c|}
\hline Description & Quantity & Expert Code \\
\hline $\begin{array}{l}\text { ITISS Project Director with } \\
35 \text { years of experience in } \\
\text { strategic IT, strategic } \\
\text { planning and IT operation. }\end{array}$ & 1 & PD \\
\hline $\begin{array}{l}\text { Public Sector Consultant } \\
\text { officer with } 35 \text { years of } \\
\text { experience in IT strategic } \\
\text { planning and data center } \\
\text { operation fields. }\end{array}$ & 1 & PSC1 \\
\hline $\begin{array}{l}\text { ITISS project manager/ } \\
\text { project leader with more } \\
\text { than } 20 \text { years of experience } \\
\text { in strategic planning and } \\
\text { operation fields. }\end{array}$ & 3 & $\begin{array}{l}\text { PM1, PM2, } \\
\text { PM3 }\end{array}$ \\
\hline $\begin{array}{l}\text { Senior executive as project } \\
\text { team member with more } \\
\text { than } 10 \text { years' experience. }\end{array}$ & 4 & $\begin{array}{l}\text { SE1, SE2, } \\
\text { SE3, SE4 }\end{array}$ \\
\hline Total & 9 & \\
\hline
\end{tabular}

Experts were chosen based on their previously worked or experience in managing or operating with a minimum of five years of experience in the field of ITISS. The selection of expert is based on skillful and possessing a depth knowledge only for the specific subject [28]. Minimum sampling for an expert can be 7 persons [29]. All the chosen experts are involved directly in the ITISS projects in MAMPU and there are the three represented ITISS case study.

\section{RESULT AND DISCUSSION}

Results from the content analysis show 52 papers discuss on the shared services and only 22 papers related to IT shared services. Surprisingly only 5 papers have mentioned about shared services quality and related to shared services in any domain [5], [22], [30]-[32]. This study compiled the service quality dimension mentioned in the 5 shared services papers as in Table 3 below:
Table 3: Dimensions of Shared Services Quality

\begin{tabular}{|c|c|c|c|}
\hline No & Reference & $\begin{array}{l}\text { Research } \\
\text { Scope }\end{array}$ & Quality Dimension \\
\hline 1. & {$[5]$} & $\begin{array}{l}\text { Human } \\
\text { Resource } \\
\text { Shared } \\
\text { Services }\end{array}$ & $\begin{array}{l}\text { Knowledge, Staffing } \\
\& \text { skills, Technology, } \\
\text { Administrative } \\
\text { support, Management } \\
\text { structures, Processes, } \\
\text { Resources, Values and } \\
\text { goals }\end{array}$ \\
\hline 2. & [22] & $\begin{array}{l}\text { Evaluating the } \\
\text { human } \\
\text { resource } \\
\text { shared } \\
\text { services } \\
\text { model } \\
\text { (HRSS) }\end{array}$ & $\begin{array}{l}\text { HR Employee, Cost } \\
\text { saving, Level of } \\
\text { specialist advice }\end{array}$ \\
\hline 3. & [32] & $\begin{array}{l}\text { Goal and } \\
\text { benefit of } \\
\text { shared } \\
\text { services from } \\
\text { Senior IT } \\
\text { Managers } \\
\text { perspective }\end{array}$ & $\begin{array}{l}\text { Professionalism, } \\
\text { Uniformity of service, } \\
\text { Personnel } \\
\text { development, Service } \\
\text { levels, Service } \\
\text { improvement }\end{array}$ \\
\hline 4. & [31] & $\begin{array}{l}\text { Measuring } \\
\text { service } \\
\text { satisfaction } \\
\text { from IT } \\
\text { Managers } \\
\text { perspective }\end{array}$ & $\begin{array}{l}\text { Service Level } \\
\text { Agreement (SLA), } \\
\text { Dedication to } \\
\text { Marketing \& } \\
\text { Awareness (M\&A), } \\
\text { Be There for the } \\
\text { Customer/Take } \\
\text { Ownership, Commit } \\
\text { to the Continuous } \\
\text { Improvement Cycle }\end{array}$ \\
\hline 5. & [8] & $\begin{array}{l}\text { Measuring the } \\
\text { performance } \\
\text { of HR shared } \\
\text { services } \\
\text { providers, HR } \\
\text { effectiveness } \\
\text { and service } \\
\text { quality. }\end{array}$ & $\begin{array}{l}\text { HR value, HR service } \\
\text { delivery, Human } \\
\text { resource management, } \\
\text { HR shared services } \\
\text { providers, HR } \\
\text { effectiveness and } \\
\text { service quality, } \\
\text { Economies of scale, } \\
\text { Efficiency } \\
\text { consolidated, } \\
\text { Knowledge resources }\end{array}$ \\
\hline
\end{tabular}

From the five shared services research stated above, only one research involves with customer satisfaction of shared services. Others slightly mentioned indirectly only the element related to service quality in the research. From those 
pieces of literature, most research focusing on Human Resource shared services and only one focus on IT Shared Services. This study focused on the exploration of the service quality for customer satisfaction which is aligned with the statement by [11] and [22] that the importance of management with a customer oriented.

Reference [22] examines the shared service model of organizing the human resource management function in four NHS organizations. It focusses on evaluating HR Employee, cost saving and level of specialist advice. The authors make a comparison of transactional, professional advisory or transformational organizational set-up activities. Reference [5] have focused on shared services research in human resource. It revealed the important factors in HRSS, that knowledge, staffing \& skills, technology, administrative support, management structures, processes, resources and value and goals.

Reference [32] highlighted that no organization was celebrating the highest level of success and none was publicly admitting to outright failure. It showed that actual dimension or attribute to measure the success of IT services is yet to be determined. In this research, it was not mentioned the dimension used to determine the level of success but instead of referring to the main goal and benefits of IT Shared Services. However, the research was quoted the method of professionalism of SSO with the clients, uniformity of services across clients, personal development to ensure the efficiency of service management and service level assurance to customers.

Reference [31] is the only paper specifically discuss measuring service satisfaction in shared services organization by interviewing the IT Managers. The author claims four factors related to service satisfaction - "A Service Level Agreement (SLA), Dedication to Marketing \& Awareness (M\&A), Be There for the Customer/Take Ownership and Commit to the Continuous Improvement Cycle". Three dimensions which are A Service Level Agreement (SLA), Dedication to Marketing \& Awareness (M\&A) and Be There for the Customer/Take Ownership are mapping to dimension in SERVQUAL which are assurance, responsiveness and tangibles accordingly. Continuous Improvement is a new dimension identified in the study.

From the literature review, it is clear that customer-oriented should be a high priority by the shared services organization [11], [32]. SSO need to ensure that focus on customer satisfaction is a priority in daily operation. All the core dimensions for shared services quality identified will be further analysed in the next research phase.

\subsection{Management of ITISS in Malaysian Public Sector}

ITISS in MPS currently operated by MAMPU to government agencies nationwide. Each ITISS have their own team focusing on their scope to deliver the best for their customers. The operations of ITISS is managed by the project team based on the scope in the contract. It is observed that MAMPU as the SSO must be focused to deliver effective IT infrastructures. These elements are vital to ensure effective service delivery. In the context of information technology, the hardware consists of IT devices such as server and cable and the software should be integrated. This infrastructure is supporting its operation in the network [11]. Any failure to the IT shared services will give a significant impact to the overall performance of IT services. The SSO is responsible to maintain a high level of service delivery in operation. Hence, the performance of ITISS under MAMPU should be evaluated to measure customer service satisfaction within different scopes of business.

All the informants mentioned that reliability, responsiveness, assurance and continuous service improvement are important dimensions that determine the service quality for ITISS. To satisfy the customers, the dimensions should deliver with quality. Due to rapid change in IT, SSO should consider high priority and attention to two dimensions namely technology availability and security. This is to ensure that SSO offers up-to-date services and high security to protect new online threat to IT infrastructure. Therefore, we concluded that the four dimensions as a core service quality in this study from the perspective of ITISS project team.

\subsection{Proposed ITISS Quality Dimensions}

Based on the reviews and interview sessions with the experts, this study concludes nine service quality dimensions that are suitable for ITISS. It shows that four dimensions identified from the previous study and SERVQUAL model agreed by all the informants whereas two dimensions agreed by 6 out of 9 informants. Although only one previous study proposed continuous service improvement dimension but it is also proposed by all the informants. PD also agreed that more dimension should be added and not limited to the information given by the informants. There are new dimensions discovered and proposed by the informant; 1) Change management, 2) Technology availability, 3) Technology security. These dimensions are highly important and will be used further to develop the ITISS customer satisfaction model. The explanation for each construct is as shown in Table 4.

Five of the dimensions, reliability, responsiveness, assurance, tangibles and empathy are adopted from SERVQUAL which is agreed upon and accepted by all the experts. We conclude that empathy, responsiveness and assurance is the professional attitude that must exist in the SSO team as suggested by [32]. The SERVQUAL dimensions have also been added to the updated DeLone \& McLean model after research shows its high convergent validity for each dimension [10]. Furthermore, an additional three dimensions are suggested from the experts in this study which are change management, technology availability and security. Since ITISS is a long-term commitment, SSO needs to have a change management plan. Enhancements will help to keep the systems relevant for customers and improve the services 
offered [29], [31], [33]. To remain competitive and to demonstrate its credibility, ITISS needs to use the latest technology [11]. Another new dimension is security which cannot be compromised [34]. Good security will gain the trust of customers and improve the efficiency of shared services for customers [35].

Table 4: Proposed ITISS Quality Dimensions

\begin{tabular}{|c|c|c|}
\hline Dimension & Descriptions & Experts \\
\hline Reliability & $\begin{array}{l}\text { Reliability means all the shared } \\
\text { services provided by the SSO } \\
\text { are always up and running } \\
\text { whenever needed by the } \\
\text { customers. This means that the } \\
\text { services have to be available } \\
24 \times 7 \text {. All party should be ready } \\
\text { to provide the service in the era } \\
\text { of digital. }\end{array}$ & $\begin{array}{l}\text { All } \\
\text { Experts }\end{array}$ \\
\hline Responsiveness & $\begin{array}{l}\text { Responsiveness is related to the } \\
\text { resolution time to solve any } \\
\text { request or incident that is } \\
\text { related to the service provided. } \\
\text { The professionalism and skill of } \\
\text { the staff of the SSO or the } \\
\text { vendor selected are very } \\
\text { important to solve the } \\
\text { customer's problem. } \\
\text { By choosing ITISS meant } \\
\text { customer anticipation more } \\
\text { towards a better service than } \\
\text { before. All issues or incidents } \\
\text { can resolve immediately } \\
\text { without having a significant } \\
\text { impact on the core business of } \\
\text { the customer. }\end{array}$ & $\begin{array}{l}\text { All } \\
\text { Experts }\end{array}$ \\
\hline Assurance & $\begin{array}{l}\text { A Service Level Agreement } \\
\text { (SLA) that meets the minimum } \\
\text { requirement of customers and } \\
\text { the availability of a skilled team } \\
\text { to solve any problem that may } \\
\text { occur. Assurance is a core } \\
\text { element to ensure service } \\
\text { quality. Each ITISS should } \\
\text { have appropriate SLA and fulfil } \\
\text { customer requirement. }\end{array}$ & $\begin{array}{l}\text { All } \\
\text { Experts }\end{array}$ \\
\hline Tangibles & $\begin{array}{l}\text { ITISS tangibles are related to } \\
\text { the overall service; which } \\
\text { involves service environment } \\
\text { such as good air-conditioning } \\
\text { and rack of hardware room, } \\
\text { excellent and knowledgeable } \\
\text { service desk and good } \\
\text { appearance of the operation } \\
\text { team. }\end{array}$ & $\begin{array}{l}\text { All } \\
\text { Experts }\end{array}$ \\
\hline Empathy & $\begin{array}{l}\text { The SSO employees are } \\
\text { concerned about the customers }\end{array}$ & $\begin{array}{l}\text { All } \\
\text { Experts }\end{array}$ \\
\hline
\end{tabular}

\begin{tabular}{|c|c|c|}
\hline & $\begin{array}{l}\text { and their problems. This refers } \\
\text { to the quality of service } \\
\text { provided by the SSO team } \\
\text { towards any request or } \\
\text { complaint by the customers. } \\
\text { Each SSO team should have } \\
\text { good communication skill and } \\
\text { knowledgeable in the subject } \\
\text { matter. }\end{array}$ & \\
\hline $\begin{array}{l}\text { Continuous } \\
\text { service } \\
\text { improvement }\end{array}$ & $\begin{array}{l}\text { Continuous service } \\
\text { improvement means the } \\
\text { services offered must always be } \\
\text { up to date with the latest } \\
\text { technology. Services with new } \\
\text { technology should be available } \\
\text { whenever needed by the } \\
\text { customers. }\end{array}$ & $\begin{array}{l}\text { All } \\
\text { Experts }\end{array}$ \\
\hline $\begin{array}{l}\text { *Change } \\
\text { management }\end{array}$ & $\begin{array}{l}\text { Continuous } \\
\text { management } \\
\text { involving the customerse } \\
\text { Change management must be } \\
\text { organized frequently with all } \\
\text { the customers to give the } \\
\text { current information about } \\
\text { ITISS. Any implementation of } \\
\text { new technology for ITISS } \\
\text { should be shared with the } \\
\text { customers as a knowledge } \\
\text { transfer activity. }\end{array}$ & $\begin{array}{l}\text { Experts } \\
\text { - PD, } \\
\text { PSC, } \\
\text { PM2, } \\
\text { PM3, } \\
\text { SE2, } \\
\text { SE4 }\end{array}$ \\
\hline $\begin{array}{l}\text { *Technology } \\
\text { Availability }\end{array}$ & $\begin{array}{l}\text { SSC must always ready and } \\
\text { prepare to provide the latest } \\
\text { technologies in the market } \\
\text { related to services provided. IT } \\
\text { technology changes rapidly. } \\
\text { Provide the latest technology } \\
\text { and ensure sustainability to the } \\
\text { customer's designated location. }\end{array}$ & $\begin{array}{l}\text { Experts } \\
\text { - PD, } \\
\text { PSC1, } \\
\text { PM1, } \\
\text { PM3, } \\
\text { SE3, } \\
\text { SE4 }\end{array}$ \\
\hline *Security & $\begin{array}{l}\text { The security of the services } \\
\text { provided is also assured. The } \\
\text { comprehensive security covers } \\
\text { according to the need of the } \\
\text { customers. Security means } \\
\text { anything involving of data, } \\
\text { information and transactions } \\
\text { while using the ITISS provided. }\end{array}$ & $\begin{array}{l}\text { Experts } \\
\text { - PSC1, } \\
\text { PM1, } \\
\text { SE1, } \\
\text { SE4 }\end{array}$ \\
\hline
\end{tabular}

Note: * New proposed dimension from experts

The proposed ITISS quality dimensions consist of nine service quality dimensions. These are depicted in Figure 1, below. 


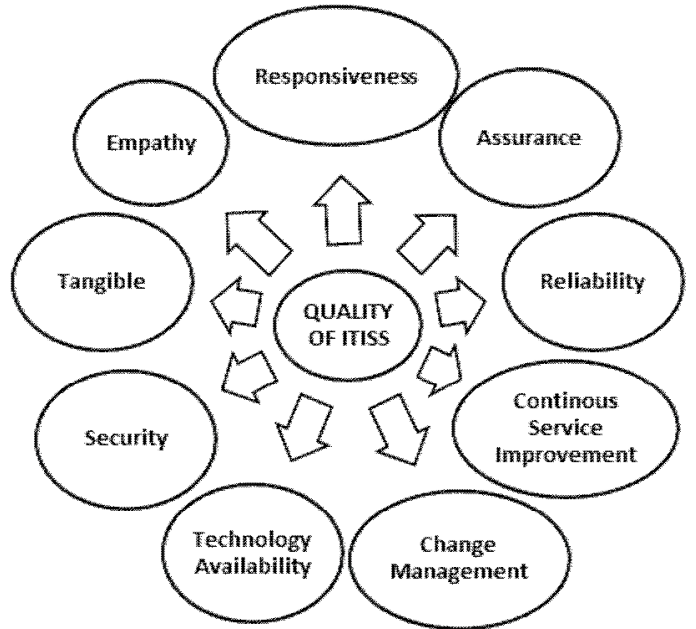

Figure 1: Initial service quality dimensions of ITISS

In the next phase, nine service quality dimensions identified will be further investigation into 3 main dimensions; functional, technical and image quality [18]. Relevancy of each of those service quality will map to each of the category evaluation of ITISS.

\section{CONCLUSION}

Customers play an important role to improve the service quality and this has been supported by literature for more than three decades in all fields. This research emphasized the determination of ITISS service quality dimensions to help the SSO in making effective planning that will improve government service delivery as a whole. The research is limited to feedback from a service provider or SSO who directly participated in the management and operation of ITISS service. This research will be further enhanced by identifying the technical quality specific to each of ITISS and further developing the instrument using service quality dimensions identified for the evaluation of customer satisfaction towards ITISS. Therefore, it is strongly believed that this research will help the SSO to enhance the overall customer satisfaction towards the ITISS provided. The results will expand the existing literature and support practitioners by providing the standard measurement for ITISS customer satisfaction to become a successful SSO.

\section{ACKNOWLEDGEMENT}

The study is financially supported by the Public Service Department of Malaysia and conducted at Software Technology and Management (SOFTAM), Universiti Kebangsaan Malaysia (UKM), 43600, Bangi Selangor, Malaysia. Thanks for the information shared by IT Shared Services project managers/team at MAMPU.

\section{REFERENCES}

[1] R. McIvor, M. McCracken, and M. McHugh. Creating outsourced shared services arrangements: Lessons from the public sector, Eur. Manag. J., vol. 29, no. 6, pp. 448-461, 2011.

https://doi.org/10.1016/j.emj.2011.06.001
[2] M. Mustafa Kamal. Shared services: Lessons from private sector for public sector domain, J. Enterp. Inf. Manag., vol. 25, no. 5, pp. 431-440, 2012. https://doi.org/10.1108/17410391211265124

[3] A. F. Yusof et al. Drivers influencing shared services adoption, J. Theor. Appl. Inf. Technol., vol. 90, no. 1, pp. 93-100, 2016.

[4] M. Janssen and A. Joha. Motives for establishing shared service centers in public administrations, Int. J. Inf. Manage., vol. 26, pp. 102-115, 2006. https://doi.org/10.1016/j.ijinfomgt.2005.11.006

[5] B. Dollery and B. Grant. Tortoises and hares: The race to shared services across australian state and territory jurisdictions, Int. J. Public Adm., vol. 33, no. 1, pp. 43-54, 2010. https://doi.org/10.1080/01900690903188792

[6] E. Fielt, W. Bandara, S. Miskon, and G. G. Gable. Exploring Shared Services from an IS Perspective : A Literature Review and Research Agenda, Commun. Assoc. Inf. Syst., vol. 34, no. 1, pp. 1001-1040, 2014.

https://doi.org/10.17705/1CAIS.03454

[7] P. C. Richter and R. Brühl. Shared service center research: A review of the past, present, and future, Eur. Manag. J., vol. 35, no. 1, pp. 26-38, 2017.

[8] J. Meijerink, T. Bondarouk, and J. K. Looise. Value creation through HR shared services: Towards a conceptual framework, Pers. Rev., vol. 42, no. 1, pp. 83-104, 2013.

[9] A. Parasuraman, L. L. Berry, and V. A. Zeithaml. Perceived service quality as a customer $\square$ based performance measure: An empirical examination of organizational barriers using an extended service quality model, Hum. Resour. Manage., vol. 30, no. 3, pp. 335-364, 1991.

[10] W. H. Delone and E. R. Mclean. The DeLone and McLean Model of Information Systems Success: A Ten-Year Update, J. Manag. Inf. Syst., vol. 19, no. 4, pp. 9-30, 2003.

[11] B. Bergeron. Essentials of Shared Services, vol. 14. Hoboken,New Jersey: John Wiley \& Sons, Inc., 2003.

[12] A. Paagman, M. Tate, E. Furtmueller, and J. De Bloom. An integrative literature review and empirical validation of motives for introducing shared services in government organizations, Int. J. Inf. Manage., vol. 35, no. 1, pp. 110-123, 2015. https://doi.org/10.1016/j.ijinfomgt.2014.10.006

[13] M. Borman and M. Janssen. Reconciling two approaches to critical success factors: The case of shared services in the public sector, International Journal of Information Management, vol. 33, no. 2. pp. 390-400, 2013.

[14] T. Olsen and R. Welke. Managerial challenges to realizing IT shared services in a public university, Transform. Gov. People, Process Policy, 2019.

[15] L. I. Forst. Shared Services Grows Up, J. Bus. Strategy, vol. 22, pp. 13-15, 2001. https://doi.org/10.1108/eb040179

[16] Fielt, Bandara, Miskon, and Gable. Exploring Shared Services from an IS Perspective: A Literature 
Review and Research Agenda, Commun. Assoc. Inf. Syst., vol. 34, no. 1, pp. 1001-1040, 2014.

[17] A. Parasuraman, L. Berry, and V. A. Zeithaml. Perceived service quality as a customer-based performance measure: An empirical examination of organizational barriers using an extended service quality model, Hum. Resour. ..., vol. 30, no. 3, pp. 335-364, 1991.

[18] C. Grönroos. A service perspective on business relationships: The value creation, interaction and marketing interface, Ind. Mark. Manag., vol. 40, no. 2, pp. 240-247, 2011.

[19] N. R. Zope, K. Anand, and D. S. Lokku. Reviewing service quality for IT services offerings: Observations in the light of service quality models and determinants, Annu. SRII Glob. Conf. SRII, pp. 43-49, 2014. https://doi.org/10.1109/SRII.2014.17

[20] A. Parasuraman, V. a Zeithaml, and L. L. Berry. A Conceptual Model of Service Quality and Its Implications for Future Research, Am. Mark. Assoc., vol. 49, no. 4, pp. 41-50, 1985.

[21] E. Grigoroudis and Y. Siskos. Customer Satisfaction Evaluation, vol. 139. 2010.

[22] T. Redman, E. Snape, J. Wass, and P. Hamilton. Evaluating the human resource shared services model: Evidence from the NHS, Int. J. Hum. Resour. Manag., vol. 18, no. 8, pp. 1486-1506, 2007.

[23] N. F. Elias, H. Mohamed, and R. R. Arridha. A study on the factors affecting customer satisfaction in online airline services A study on the factors affecting customer satisfaction in online airline services, Int. Journal of Business Information Systems, vol. 20, no. 3, pp. 274-288, 2015. https://doi.org/10.1504/IJBIS.2015.072249

[24] S. S. Alam. An Investigation into the Antecedents of Customer Satisfaction of Online Shopping, Journal of Marketing Development and Competitiveness, vol. 5, no. 1, pp. 71-78, 2010.

[25] M. A. Uppal, S. Ali, and S. R. Gulliver. Factors determining e-learning service quality, British Journal of Educational Technology, vol. 49, no. 3, pp. 412-426, 2018.

[26] Unit Perancangan Ekonomi Jabatan Perdana Menteri. Rancangan Malaysia Kesebelas. Kertas Strategik 15: Memacu Teknologi Maklumat dan Komunikasi dalam Ekonomi Berasaskan Pengetahuan, 2015.

[27] R. K. Yin. Case Study Research Design and Methods, Fourth Edi. SAGE Publications, Inc, 2009.

[28] F. Hasson, S. Keeney, and H. McKenna. Research guidelines for the Delphi survey technique, $J . A d v$. Nurs., vol. 32, no. 4, pp. 1008-1015, 2010.

[29] P. M. Mullen. Delphi: Myths and reality, J. Health Organ. Manag., vol. 17, no. 1, pp. 37-52, 2003.

[30] J. Meijerink and T. Bondarouk. Exploring the central characteristics of HR shared services: Evidence from a critical case study in the Netherlands, Int. $J$. Hum. Resour. Manag., vol. 24, no. 3, pp. 487-513, 2013.

[31] R. Marciniak. Measuring Service Satisfaction in
Shared Service Organizations, Procedia - Soc. Behav. Sci., vol. 81, pp. 217-223, 2013. https://doi.org/10.1016/j.sbspro.2013.06.416

[32] J. D. McKeen and H. A. Smith. Creating IT Shared Services, Commun. Assoc. Inf. Syst., vol. 29, 2011.

[33] C. Grönroos. A Service Quality Model and its Marketing Implications, Eur. J. Mark., vol. 18, no. 4, pp. 36-44, 1984.

[34] J. Santos. E-service quality: A model of virtual service quality dimensions, Manag. Serv. Qual. An Int. J., vol. 13, no. 3, pp. 233-246, 2003. https://doi.org/10.1108/09604520310476490

[35] G. Grant, S. McKnight, A. Uruthirapathy, and A. Brown. Designing governance for shared services organizations in the public service, Gov. Inf. Q., vol. 24, no. 3, pp. 522-538, 2007. https://doi.org/10.1016/j.giq.2006.09.005 